\title{
Luchas rituales rarámuri
}

\section{Rarámuri Ritual Fights}

Fecha de recepción: 19/06/2021

Fecha de aceptación: 21/06/2021

Fecha de publicación: 01/09/2021

https://doi.org/10.48102/if.2021.v1.n2.192

\section{Carlo Bonfiglioli*}

carlobon@unam.mx

Doctor en Ciencias Antropológicas

Universidad Nacional Autónoma de México

México

\section{Palabras clave}

Luchas rituales, ritual, rarámuri, Semana Santa, Tehuerichi.

\section{Keywords}

Ritual fights, ritual, rarámuri, Holy Week, Tehuerichi.

* Realizó sus estudios de grado en la Escuela Nacional de Antropología e Historia y de maestría y doctorado en la Universidad Autónoma Metropolitana. Ha coordinado dos proyectos interinstitucionales e interdisciplinarios: el primero sobre una Perspectiva sistémica del Noroeste de México y el segundo sobre Ontología indígenas americanas. Su campo de indagación actual apunta a una "teoría rarámuri del chamanismo".

Bonfiglioli, C. (2021) Luchas rituales rarámuri. Iberoforum Revista de Ciencias Sociales, Nueva Época, 1(2) 1-26, Ensayos fotográficos, e000192. https://doi.org/10.48102/if.2021.v1.n2.192 
Las luchas rituales tratadas en este trabajo son parte del contexto ceremonial de la Semana Santa en Tehuerichi, comunidad a la que, salvo por un paréntesis de seis años, he regresado con regularidad desde 1987. En estos treinta y cuatro años, he visto crecer a dos generaciones de rarámuri y "partir" a la mayor parte de la gente mayor que me recibió. También he asistido a la conexión vehicular de Tehuerichi con el resto del mundo por medio de dos carreteras; conexión que ha traído más cambios en veinticinco años que lo acaecido en los últimos cuatro siglos. Debo enfatizar que, debido al efecto migratorio producido por estas dos carreteras, las nuevas generaciones de rarámuri son muy diferentes a la que conocí inicialmente. Aun así, se puede afirmar que su ritualidad se ha mantenido pese a los cambios, comenzando por la Semana Santa y por las luchas rituales con las cuales termina. A continuación, hablaré de ambas cosas para contextualizar las imágenes que voy a presentar.

En correspondencia con el inicio de la cuaresma católica, a todos los hombres se les dibuja una cruz blanca en la frente, lo que puede considerarse la apertura oficial del ciclo. A partir de los domingos siguientes, los Fariseos comienzan a descubrir y pintar el cuerpo con tierra caliza. Aparecen también los dibujos astrales pintados en su parafernalia mientras que el sonido de los tambores anuncia su llegada al kawí (mundo-casa) rarámuri. Poco a poco, tanto sus danzas circulares, las procesiones, como el ethos ceremonial ganan intensidad, signo de un adueñamiento territorial inequívoco. Al aproximarse la Semana Mayor, aparece también el grupo antagonista: los Soldados. Ambos grupos llevan armas y la naturaleza de sus danzas es de tipo guerrero. El Jueves Santo, los Fariseos sacan al Judas - su líder-, un monigote fálico vestido a la manera mestiza. El Viernes 
Santo, se realizan unas largas sesiones de danzas y procesiones alrededor del templo, tanto en la mañana como en la tarde. Generalmente, al final del día, los Soldados arrebatan el monigote a sus contrincantes, disparando con ello un clima de juego y exaltación ritual notable. El Sábado de Gloria, después de otra larga sesión de danzas y procesiones, los grupos se alistan para llevar a cabo la "quema del Judas"; los Soldados se paran en el patio de los nawésari, arrojan al Judas por el suelo y, finalmente, tras mutilarlo, lo matan con lanzazos, flechazos y balazos (reales). Un cerillo acabará con él hasta volverlo cenizas.

Con este acto, hemos llegado al momento más esperado tanto por los agentes rituales como por quienes asisten a la ceremonia: el de las luchas finales. En éstas se enfrentan un Soldado y un Fariseo; los dos escogidos por el Capitán de los Soldados - la figura de mayor cargo en esta época ritual- en virtud de una supuesta equivalencia de fuerza y masa corporal. Los dos luchadores se agarran por las fajas que ciñen sus taparrabos y cada uno intenta derribar al adversario. En todo esto, la fuerza es importante, desde luego, pero, cuando ésta es equivalente, entonces la "maña" es primordial, es decir, mantener amplias las bases de apoyo y saber captar las debilidades del adversario para llevarlo al punto de desequilibrio. Por lo visto, reconocí dos tipos de estrategias para tumbar al contrincante. La primera es escoger el momento apropiado para levantarlo y hacerlo caer de espalda, lo cual puede ser una tarea complicada puesto que el "levantado" siempre busca aterrizar con los pies firmes, hacia atrás. La segunda es levantar al otro luchador y hacerlo girar 360 grados para que, al momento de tocar el piso, se desequilibre por inercia rotatoria; el problema de esta táctica es que el adversario puede utilizar esta misma 
inercia para agarrar fuerza y voltear a su contrincante. También cabe precisar que no todas las luchas terminan con un ganador; al contrario, es frecuente que concluyan en un empate: cuando el capitán de los Soldados, quien funge como juez, considera que ninguno de los luchadores muestra suficiente fuerza para prevalecer sobre el otro, suspende la confrontación y declara el empate.

Quiero cerrar esta breve descripción de la lucha con un detalle que me parece importante, a pesar de que, con el pasar de los años, su presencia se ha ido debilitando. Me refiero a la copulación (simulada) entre los contrincantes. Si el ganador logra tirar al perdedor al suelo con las piernas abiertas, puede aprovecharse de él echándose encima y fingir una copulación. Con ello, no sólo se recalca la posición de "vencido" sino también se le asigna la posición simbólica de "mujer". Dado el contexto de transgresión cómico-sexual que atraviesa la Semana Santa, este "acto copulatorio" parece apuntar a un "derrame anímico de semen" que conectaría, en una suerte de continuum relacional, la aparición del monigote fálico llamado Judas con el carácter femenino del vencido y con la fertilidad de la tierra.

En este punto, me permito un "paréntesis cosmológico" para terminar. De acuerdo con un saber bastante difundido en la región, el mundo en el que vivimos no es el único habitado: arriba y abajo hay otros mundos que también lo están. "Arriba" viven Onorúame-Sol (el creador) y sus ayudantes, los Soldados; mientras que "abajo" habitan sus contrarios: Diablo, Judas y los Fariseos (o Judíos). Son ellos los protagonistas de la confrontación que nos ocupa, cuyo antecedente mítico refiere -tal como lo consignó Lumholtz en un mito reportado a principios del siglo XX en su obra El México desconocido- a la lucha entre Tata Dios (Onorúame) 
y Diablo, padres cosmológicos de los rarámuri y de sus primos los blancos-mestizos, respectivamente. En aquel mito, del que ya no queda rastro en las narraciones de los rarámuri actuales, el "objeto" de la confrontación fue la esposa de Tata Dios, quien fue violada por Diablo en una tesgüinada aprovechándose del estado etílico de su hermano. De la lucha que se originó a raíz de esa violación, se produjo la disyunción cosmogónica primaria entre Onorúame y Diablo. El primero - ganador- se fue arriba; el otro, abajo, llevándose consigo el dinero y las armas, además de adueñarse del agua que se encuentra en esa parte del cosmos.

Dada esta premisa cosmológica, la Semana Santa vendría a ser el periodo del año en el que se recrea y revive esa conjunción conflictiva primaria, de la cual las luchas rituales son una expresión. A través de éstas, los rarámuri actuales buscan controlar los efectos relacionados con la llegada de los Fariseos, convirtiéndolos en traedores de lluvia y productores de fertilidad.

Hasta aquí, pues, la contextualización de mi trabajo fotográfico. Desde luego, las imágenes que presento a continuación -tomadas en 2002, 2004 y 2015- sólo muestran unos cuantos aspectos de lo antes dicho, siendo el tema de la virilidad el preponderante estético de éste. Los lectores tendrán que imaginar el resto o completarlo con los referentes bibliográficos citados y los registros que abundan en la red.

Buena visión.

\section{Referencias bibliográficas}

Bonfiglioli, C. (1995). Fariseos y Matachines en la Sierra Tarahumara: Entre

Bonfiglioli, C. (2021). Luchas rituales rarámuri. Iberoforum. Revista de Ciencias Sociales, Nueva Época, 1(2) 1-26, Ensayos fotográficos, e000192. https://doi.org/10.48102/if.2021.v1.n2.192

Licencia Pública Internacional - CC BY-NC-ND 4.0 
la Pasión de Cristo, la transgresión cómico-sexual y las danzas de Conquista. Instituto Nacional Indigenista, Secretaría de Desarrollo Social.

Bonfiglioli, C., Gutiérrez, A. y Olavarría, M. E. (2004). De la violencia mítica al "mundo flor". Transformaciones de la Semana Santa en el Norte de México. Journal de la société des américanistes, 90(1), 57-91. 


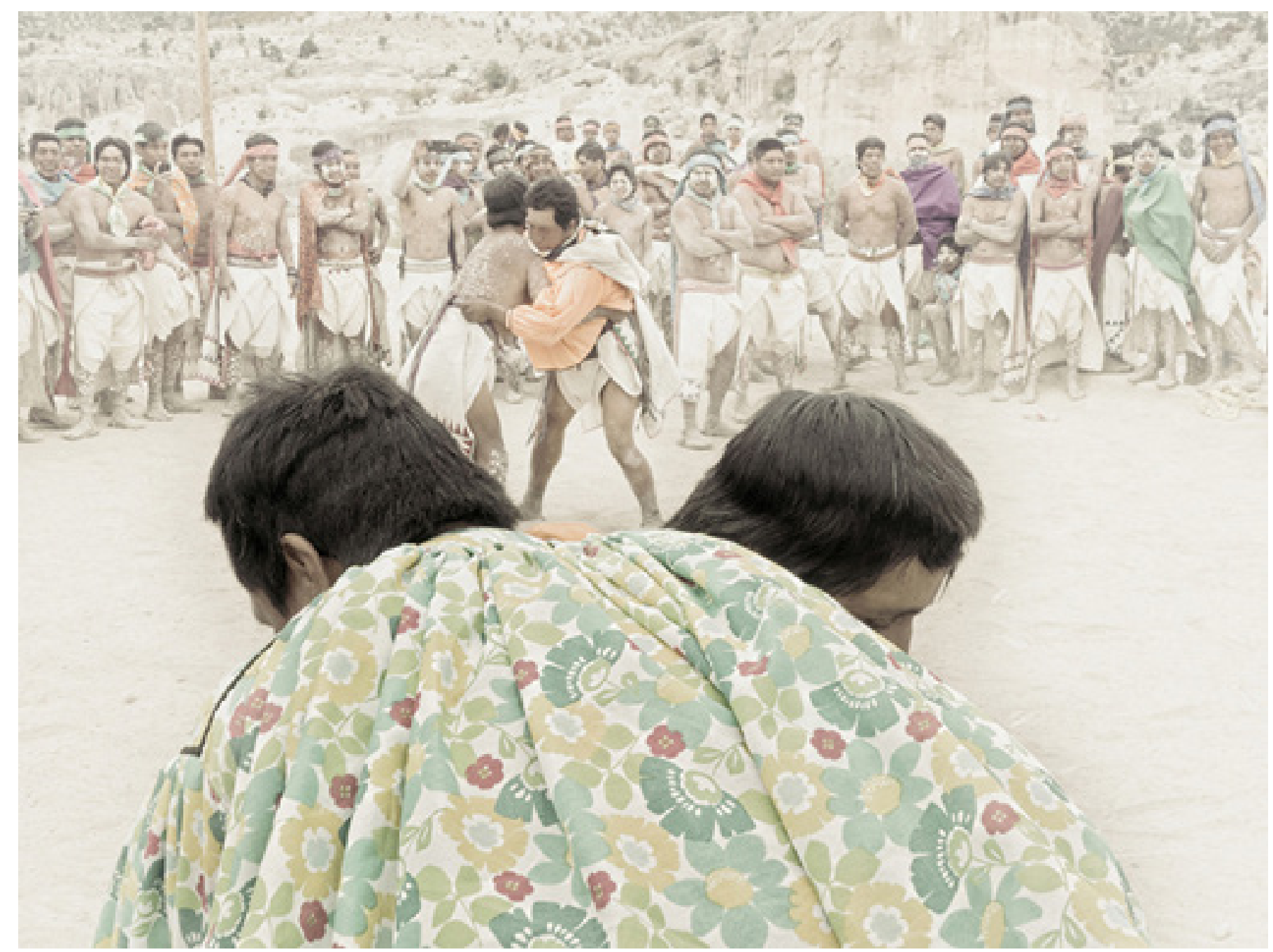

Tehuerichi, abril de 2015
Escenas de las luchas rituales con las cuales se concluye el ciclo de Semana Santa. Tal como se comenta en el texto, las luchas se realizan entre un Fariseo (reconocible por el torso desnudo) y un Soldado. El ganador será el que logre tumbar a su adversario de espalda al piso. Si, dentro de un tiempo razonable, ninguno de los contendientes logra su propósito, el juez (el Capitán de los Soldados) declarará el empate. 


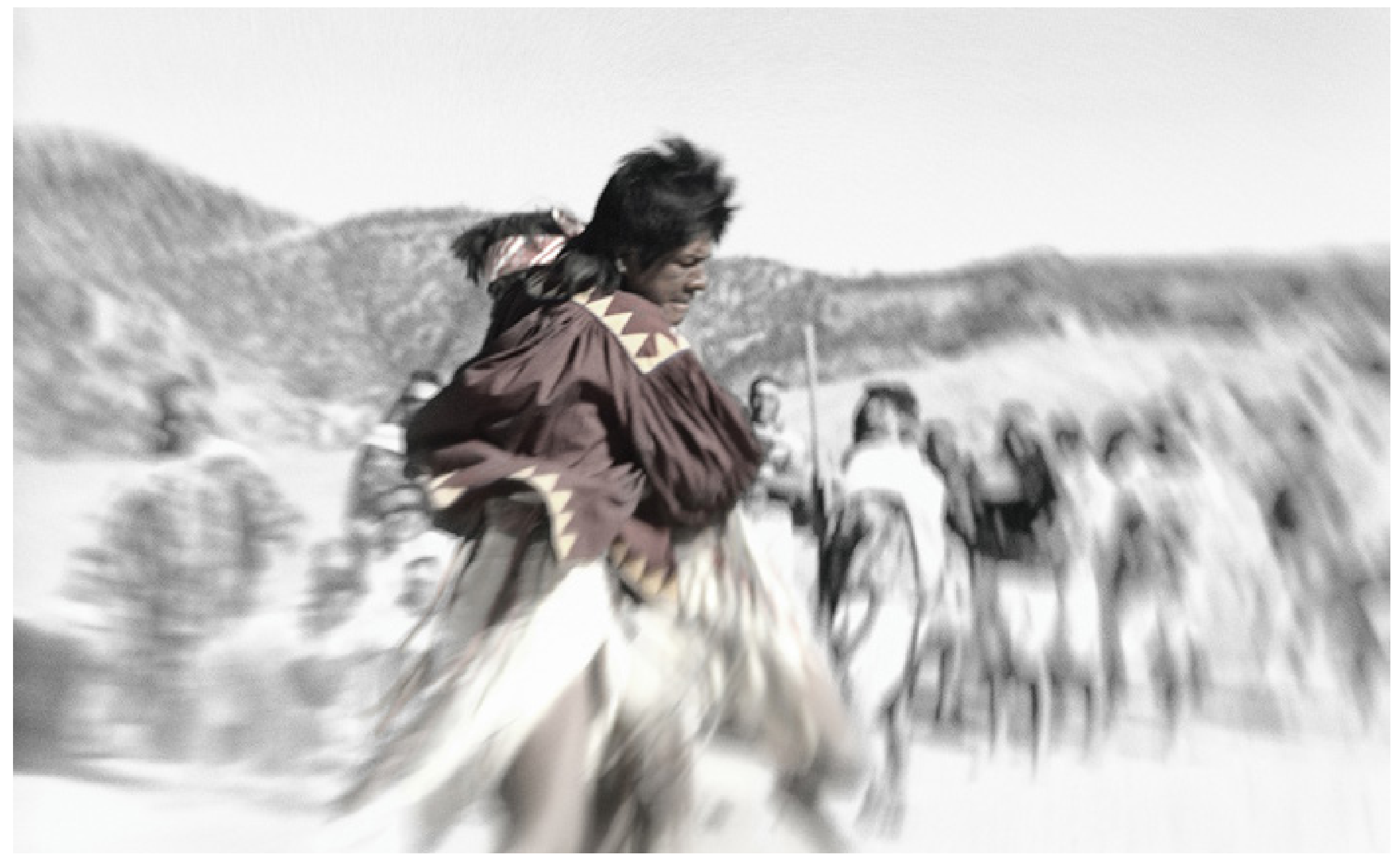

Tehuerichi, abril de 2015

Bonfiglioli, C. (2021). Luchas rituales rarámuri. Iberoforum. Revista de Ciencias Sociales, Nueva Época, 1(2), 1-26, Ensayos fotográficos, e000192. https://doi.org/10.48102/if.2021.v1.n2.192 


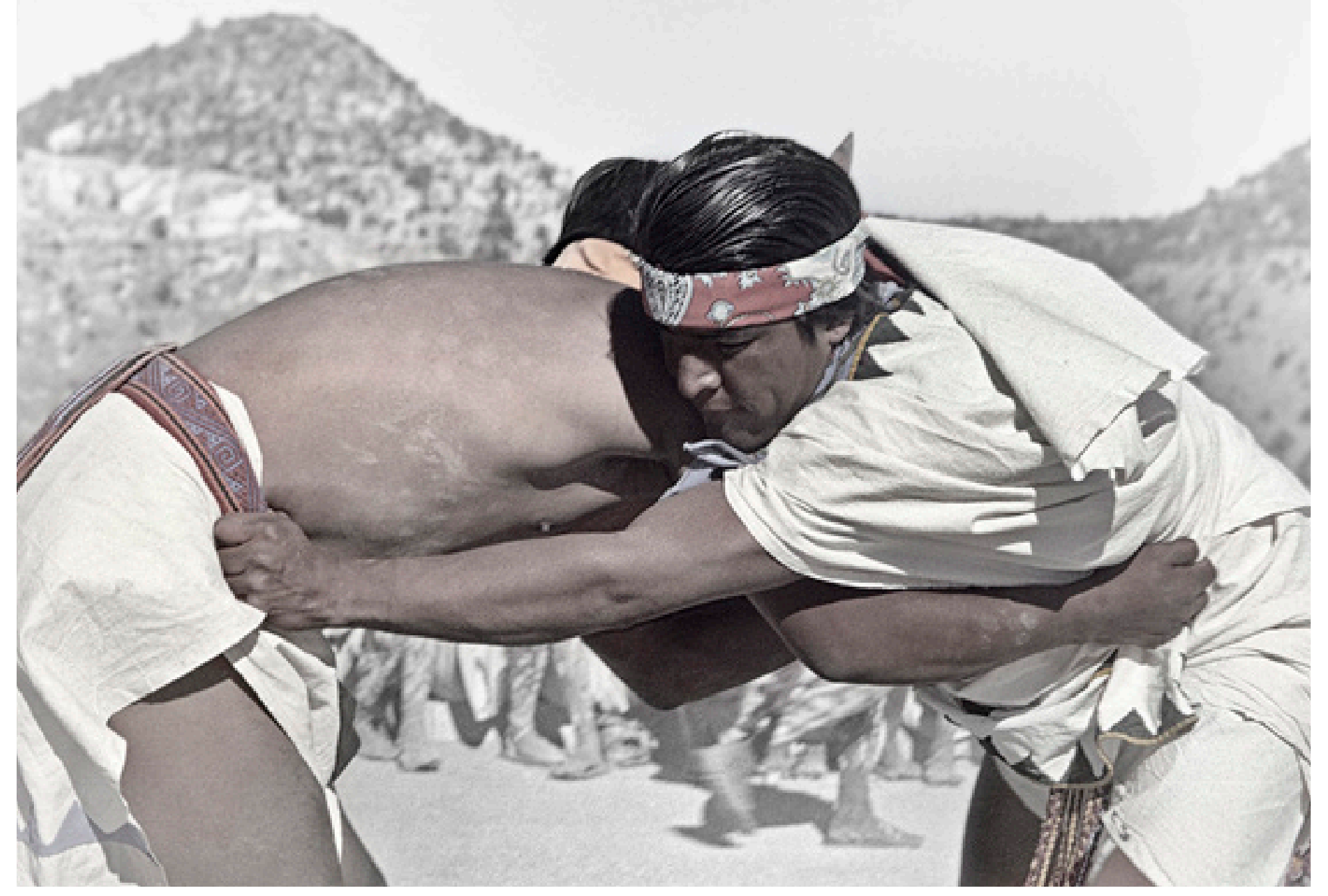

Tehuerichi, abril de 2015

Bonfiglioli, C. (2021). Luchas rituales rarámuri. Iberoforum. Revista de Ciencias Sociales, Nueva Época, 1(2), 1-26, Ensayos fotográficos, e000192. https://doi.org/10.48102/if.2021.v1.n2.192 


\section{Tehuerichi, abril de 2004}

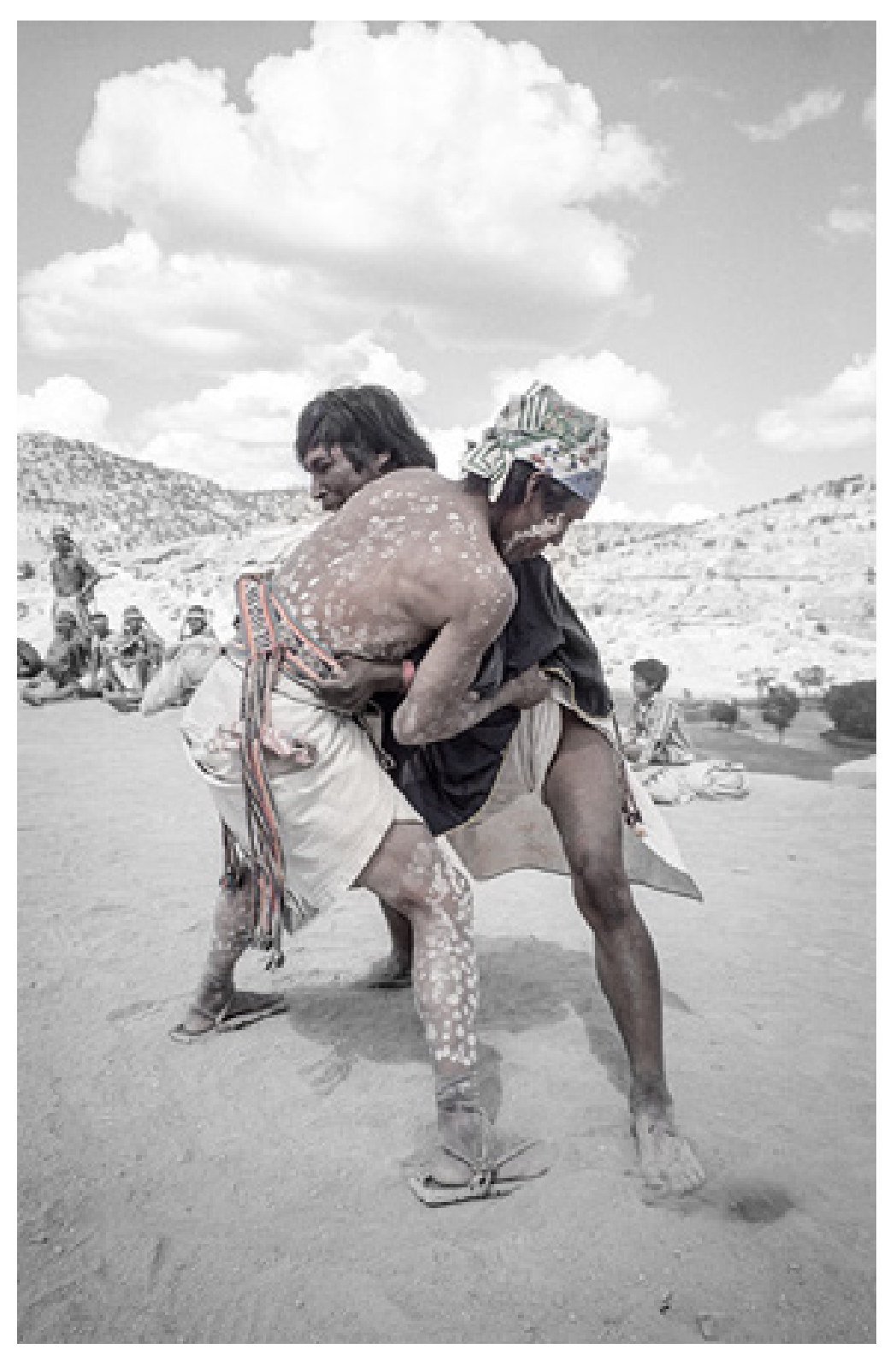




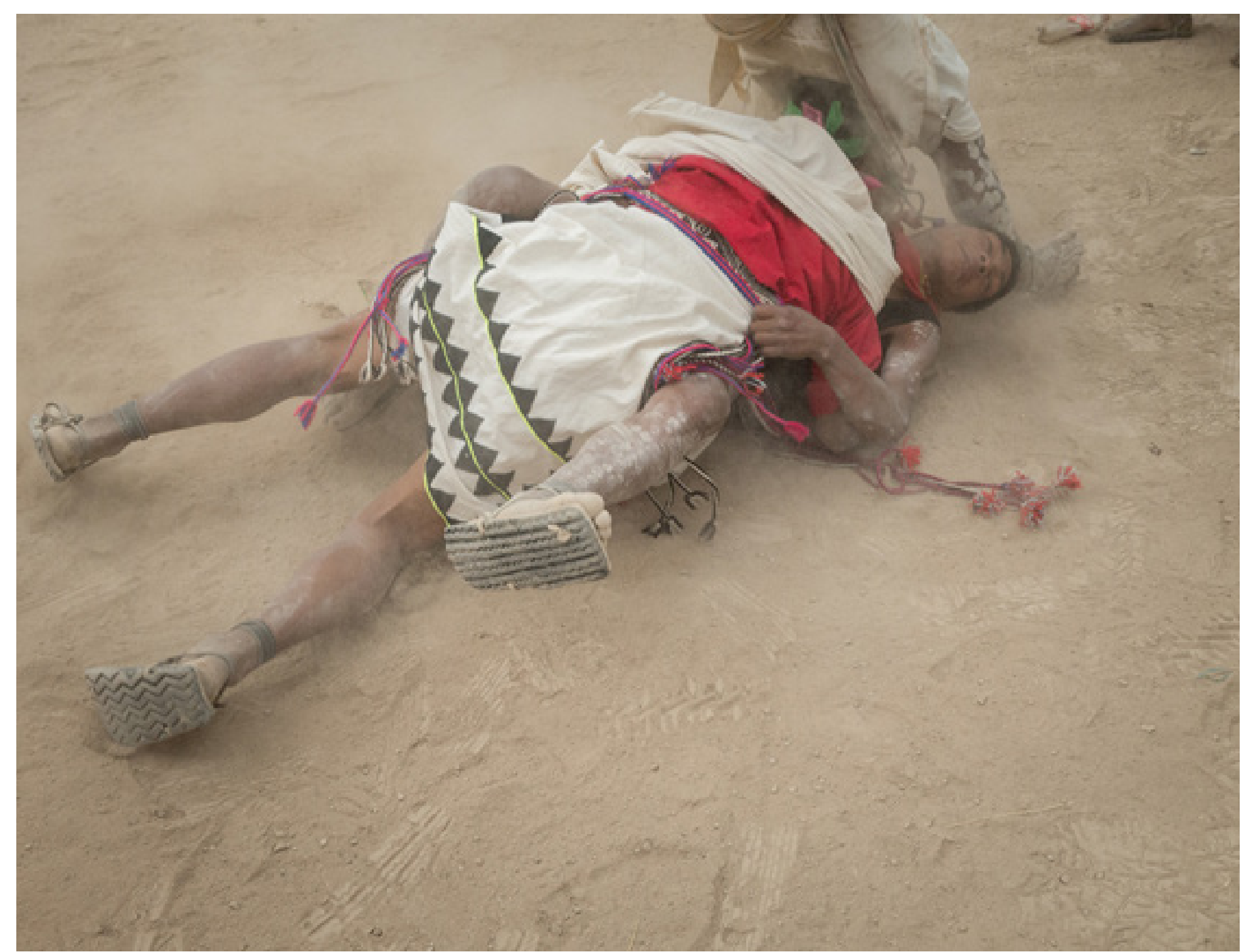

Tehuerichi, abril de 2015

Bonfiglioli, C. (2021). Luchas rituales rarámuri. Iberoforum. Revista de Ciencias Sociales, Nueva Época, 1(2), 1-26, Ensayos fotográficos, e000192. https://doi.org/10.48102/if.2021.v1.n2.192 Licencia Pública Internacional - CC BY-NC-ND 4.0 


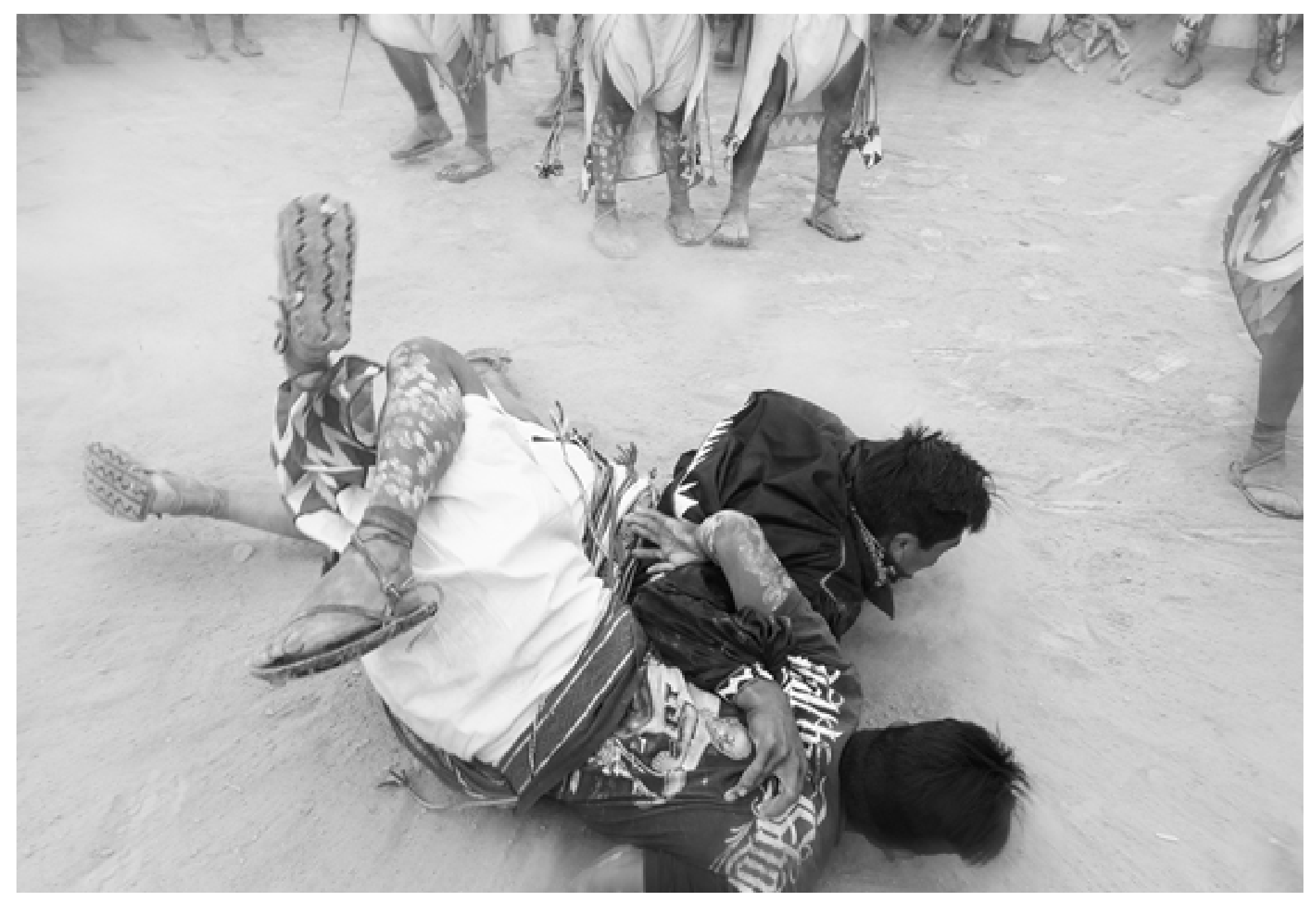

Tehuerichi, abril de 2015 


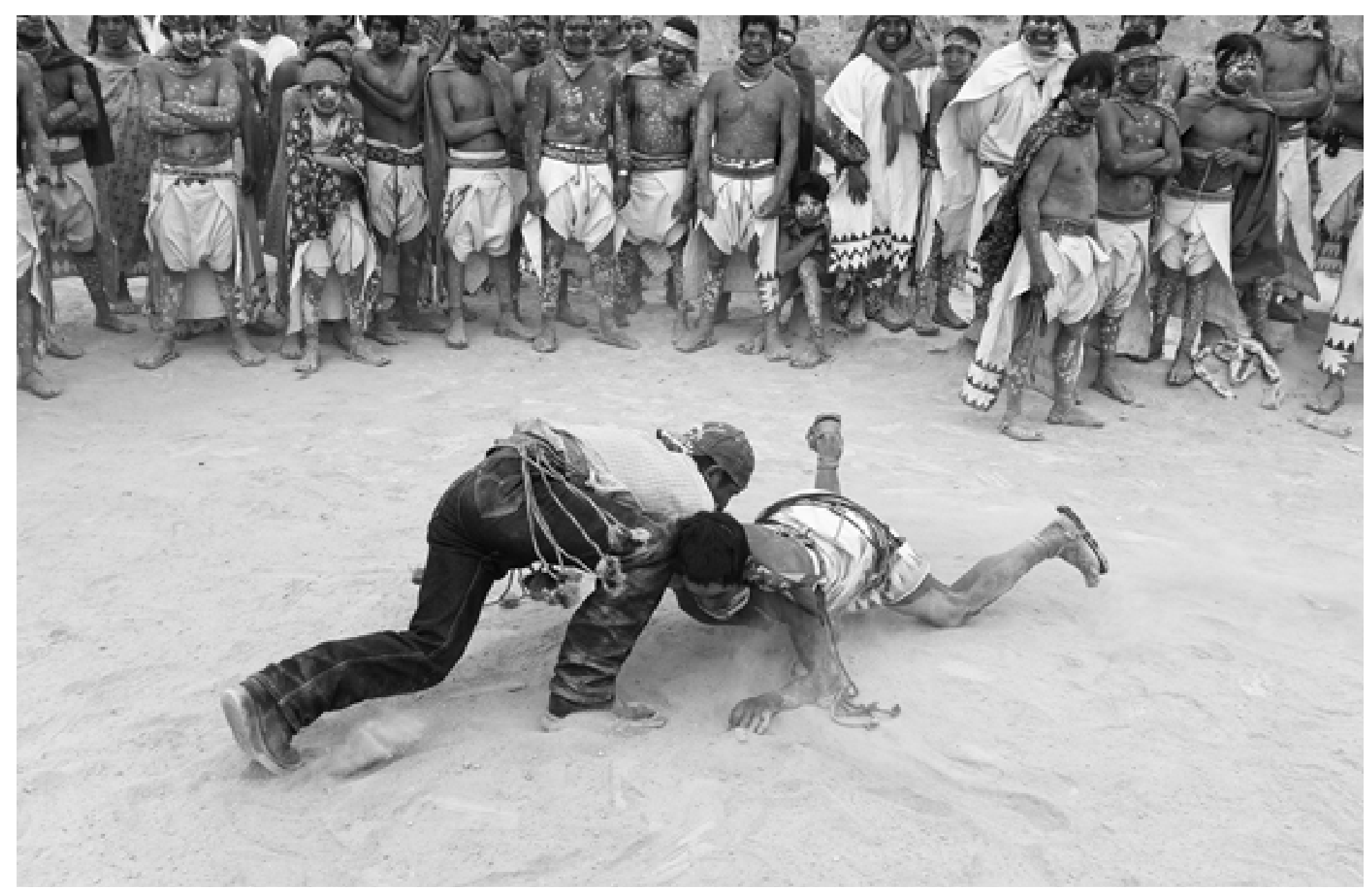

Tehuerichi, abril de 2015
En este caso, dado que ninguno de los contendientes termina con la espalda en el piso,

la lucha recomenzará o bien será declarado el empate. 


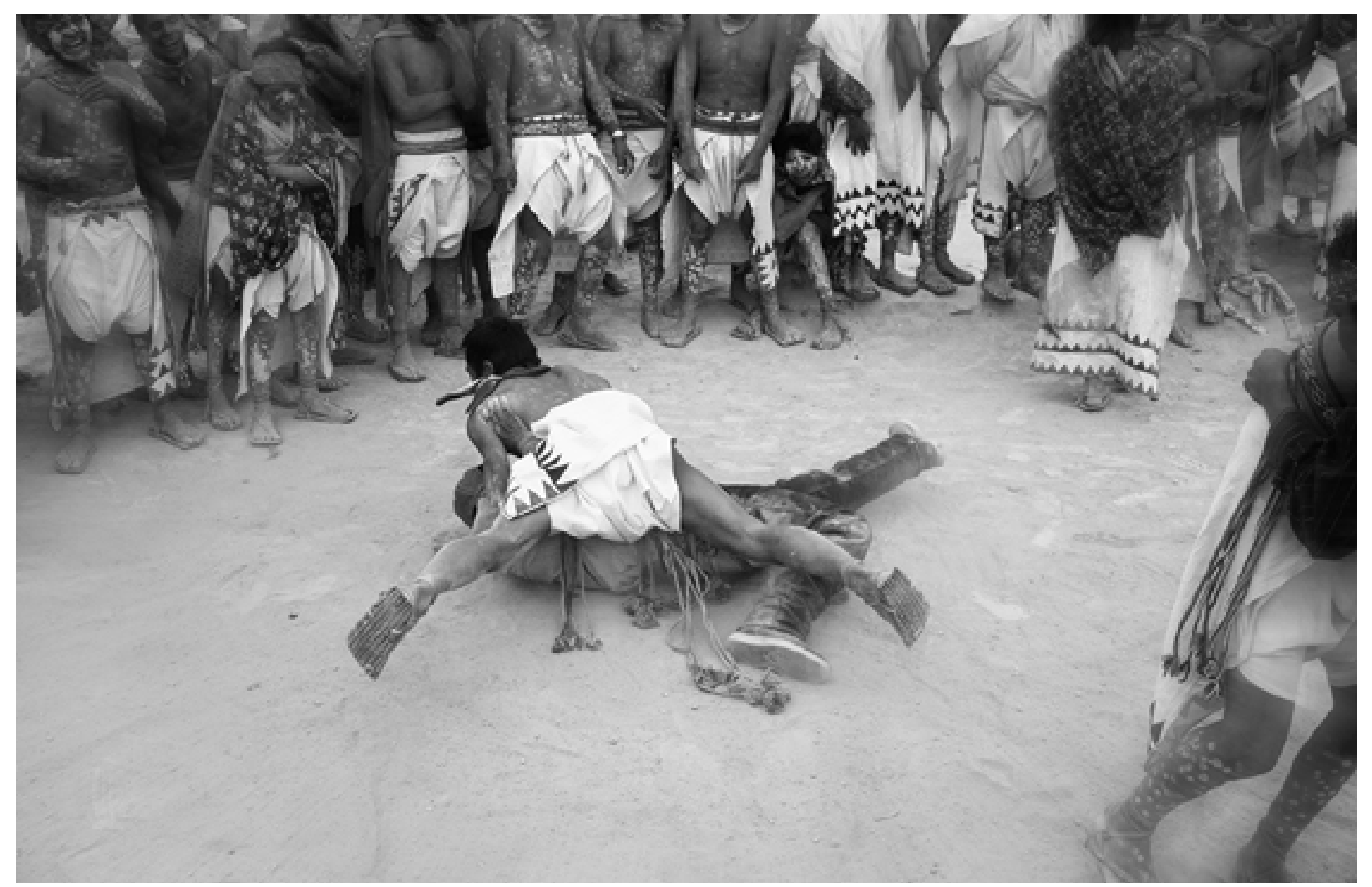

Tehuerichi, abril de 2015 


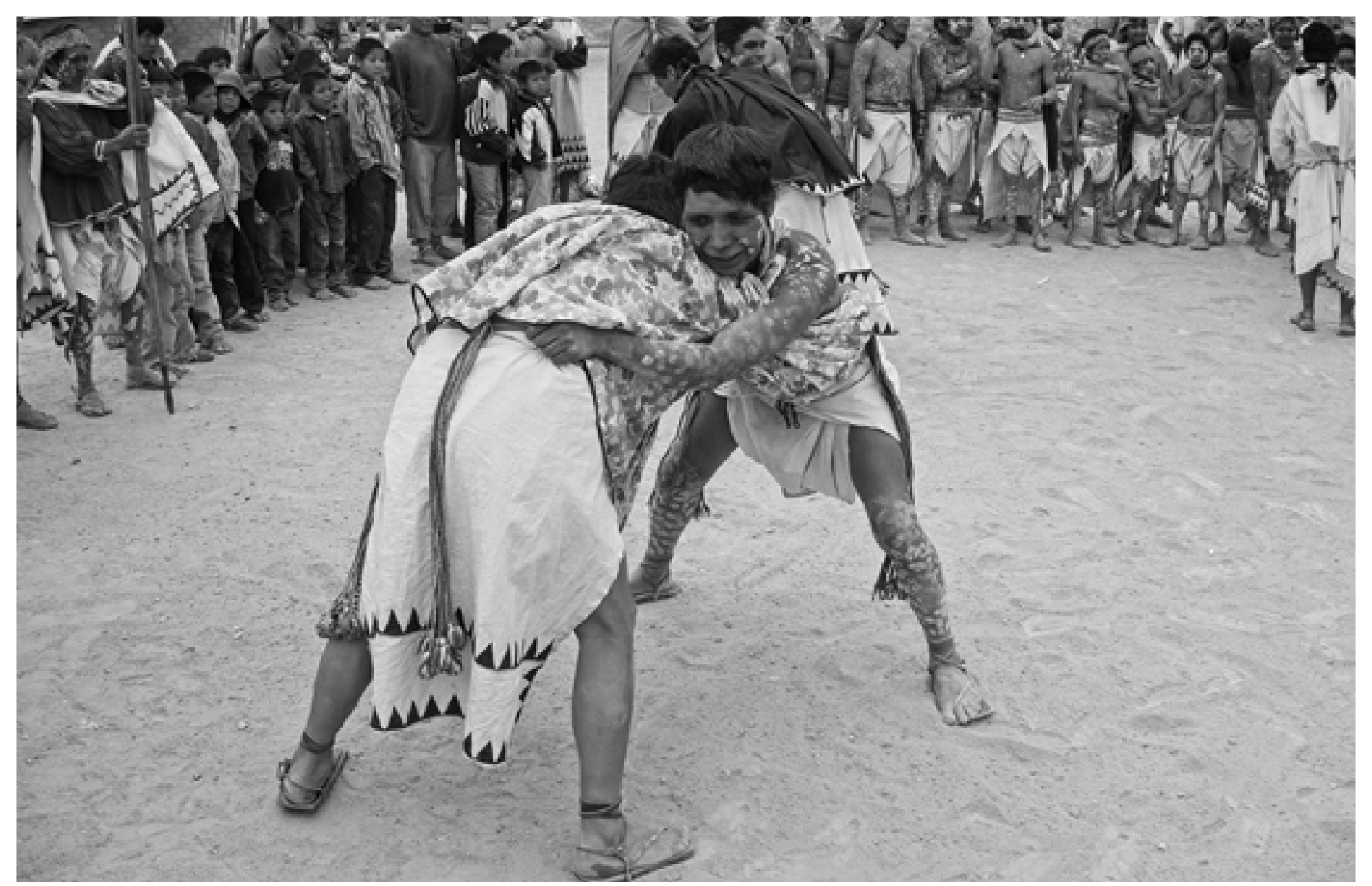

Secuencia 1. Tehuerichi, abril de 2015 


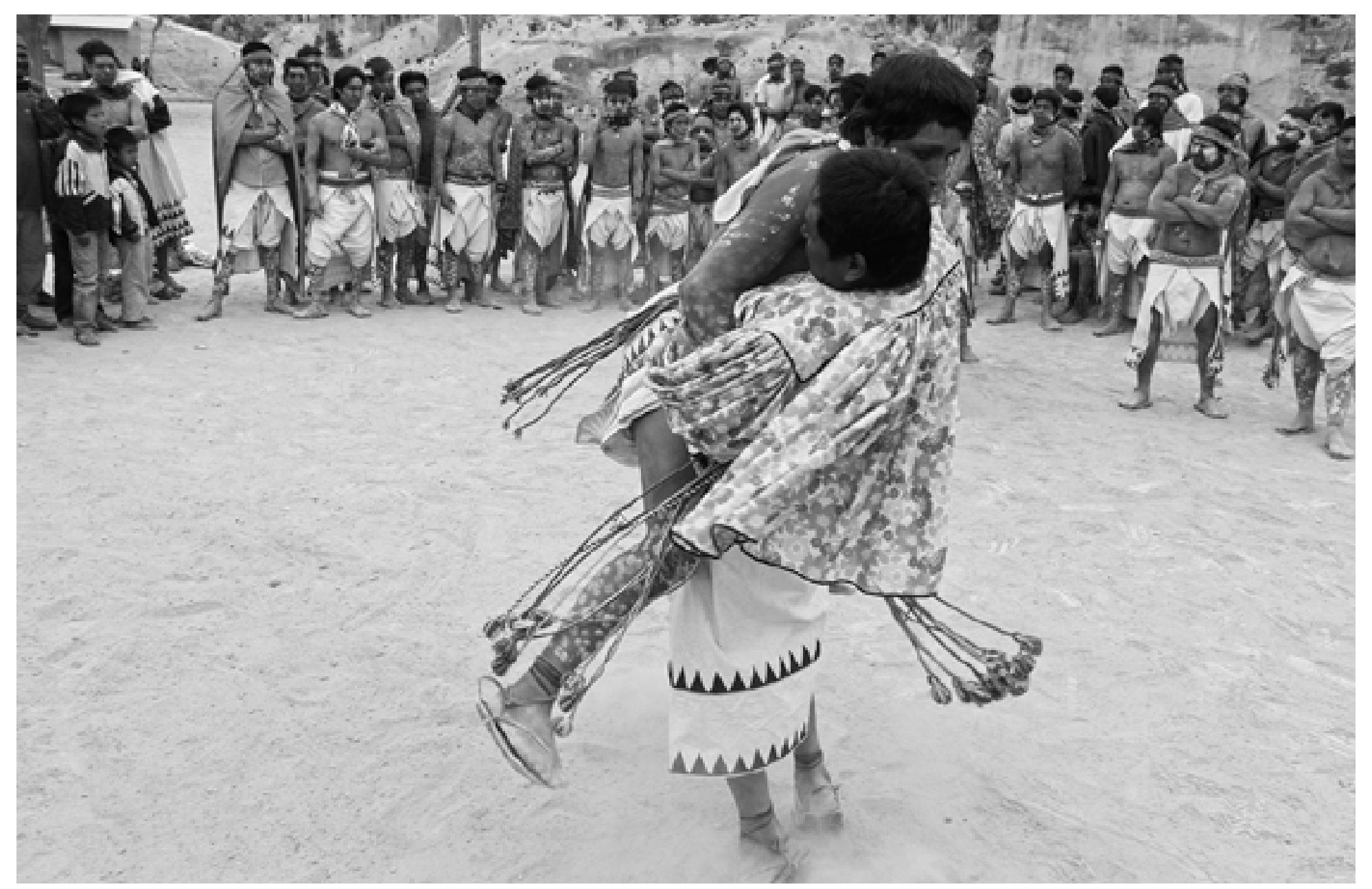

Secuencia 2. Tehuerichi, abril de 2015 


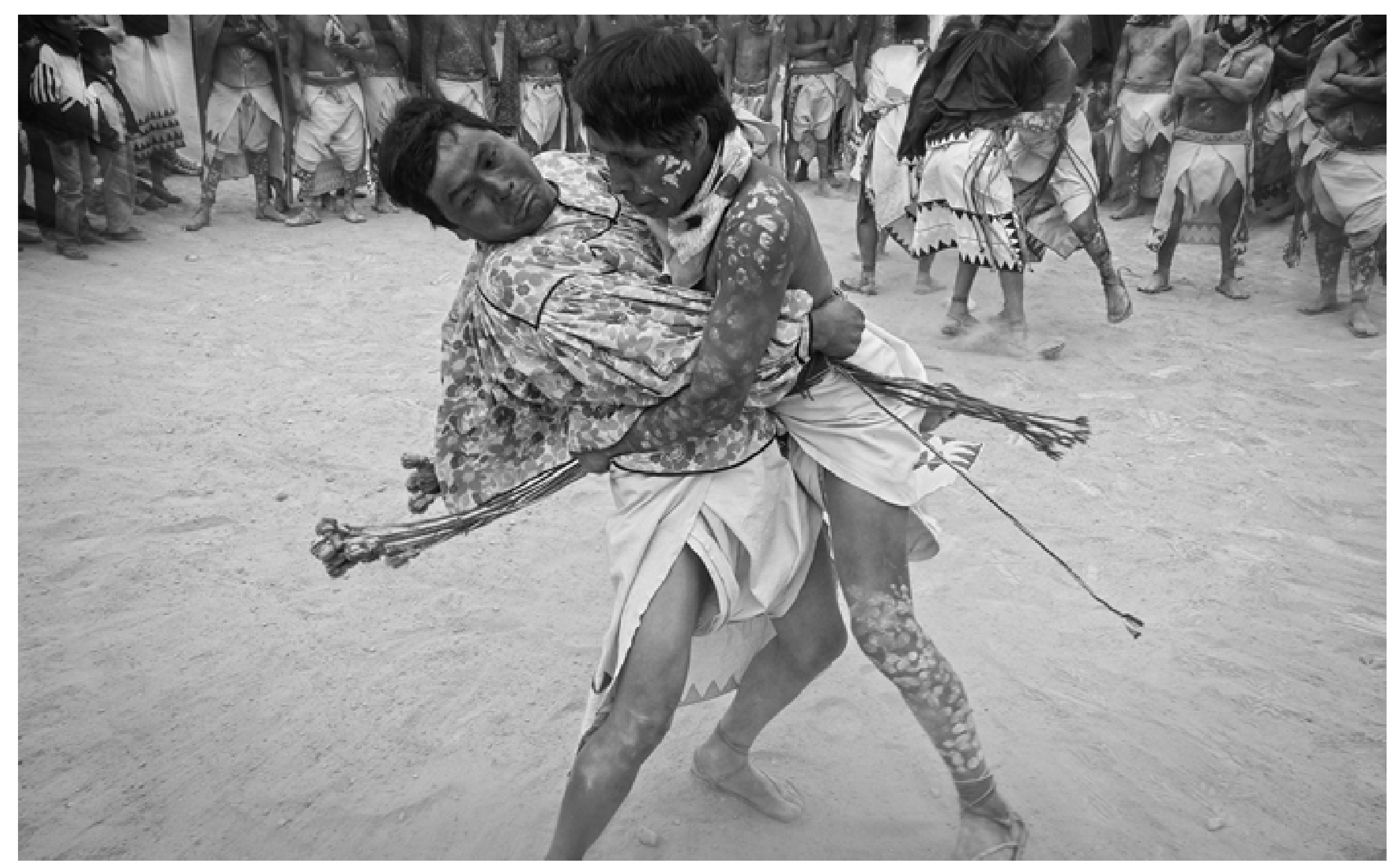

Secuencia 3. Tehuerichi, abril de 2015 


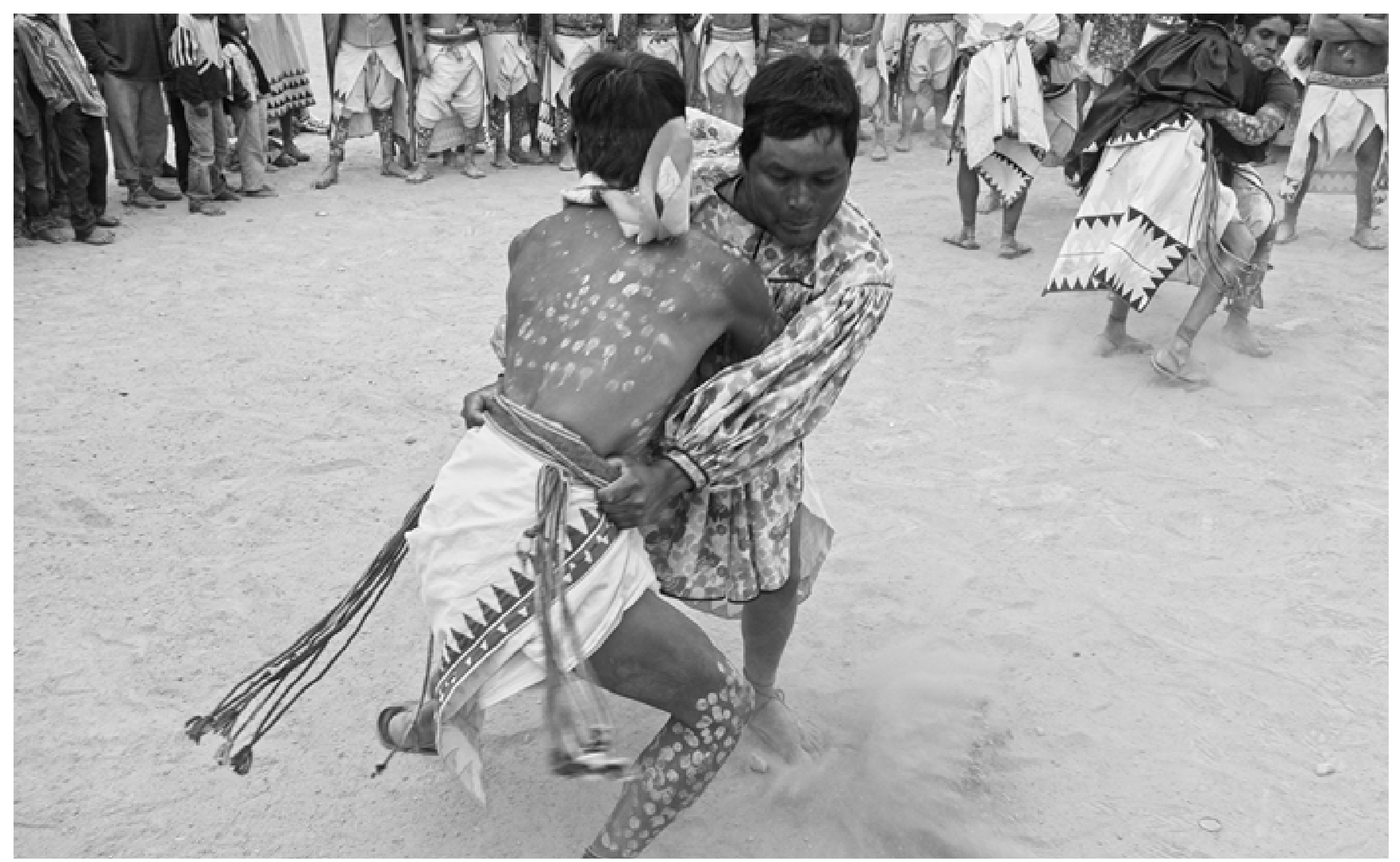

Secuencia 4. Tehuerichi, abril de 2015 


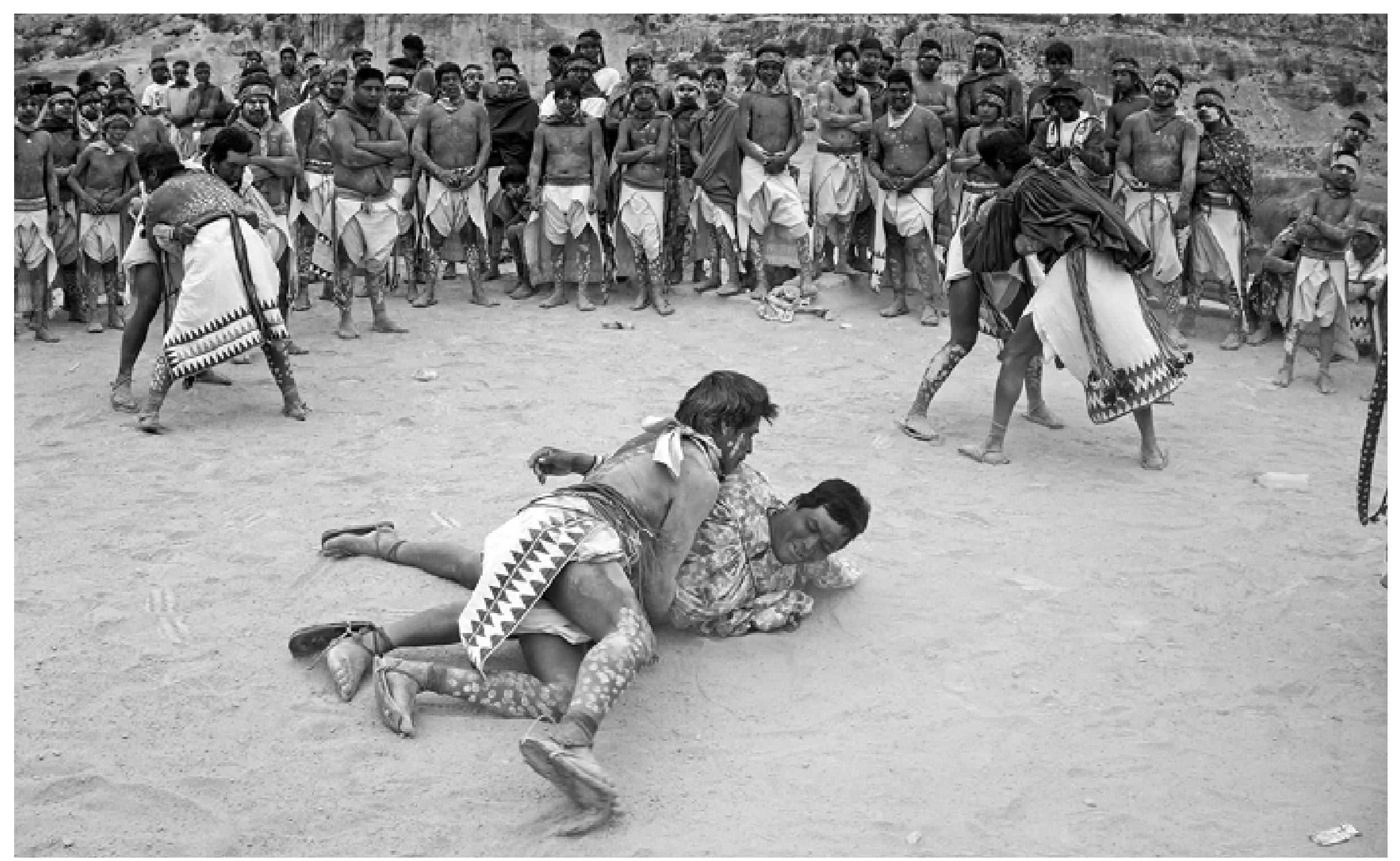

Secuencia 5. Tehuerichi, abril de 2015 


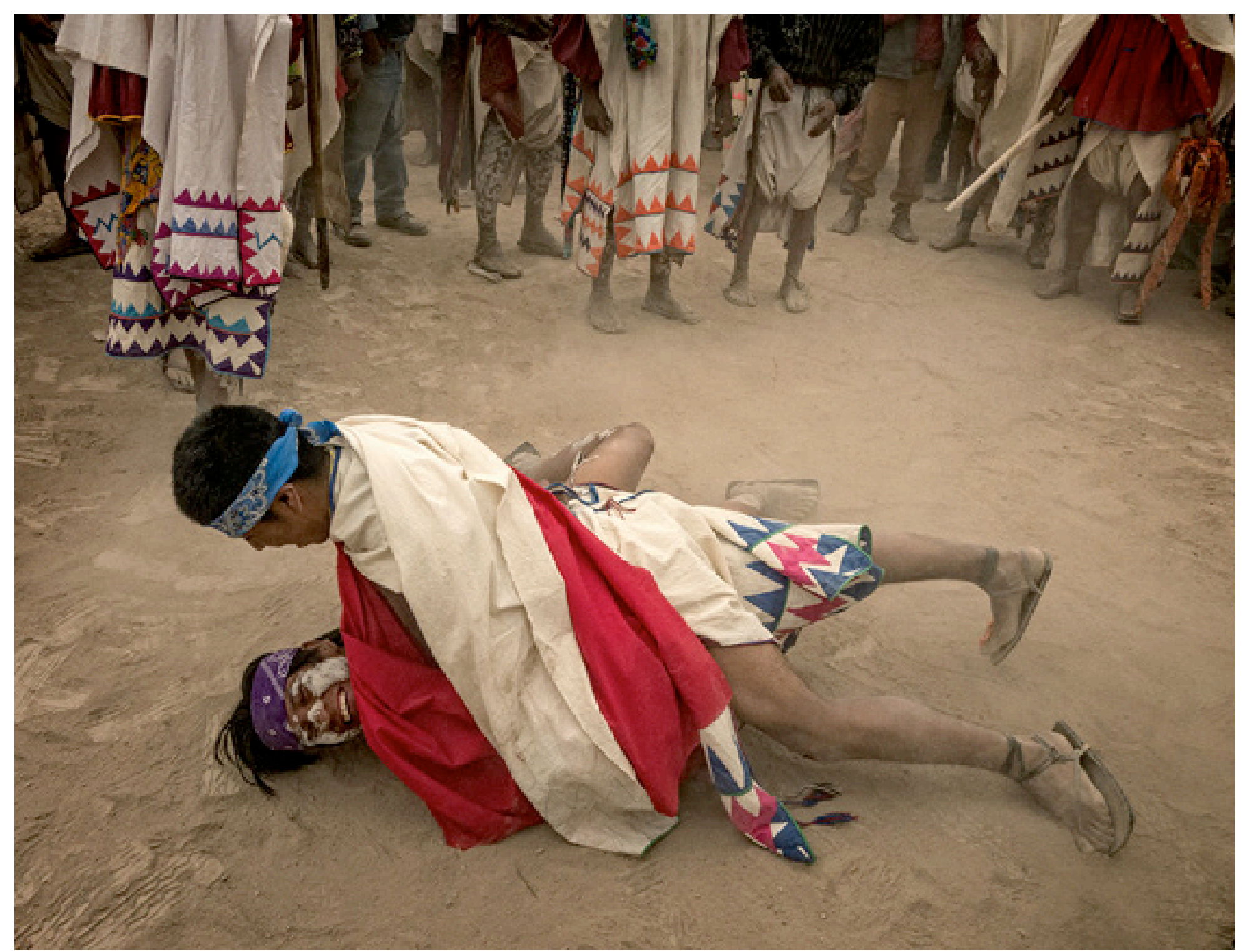

Tehuerichi, abril de 2015 


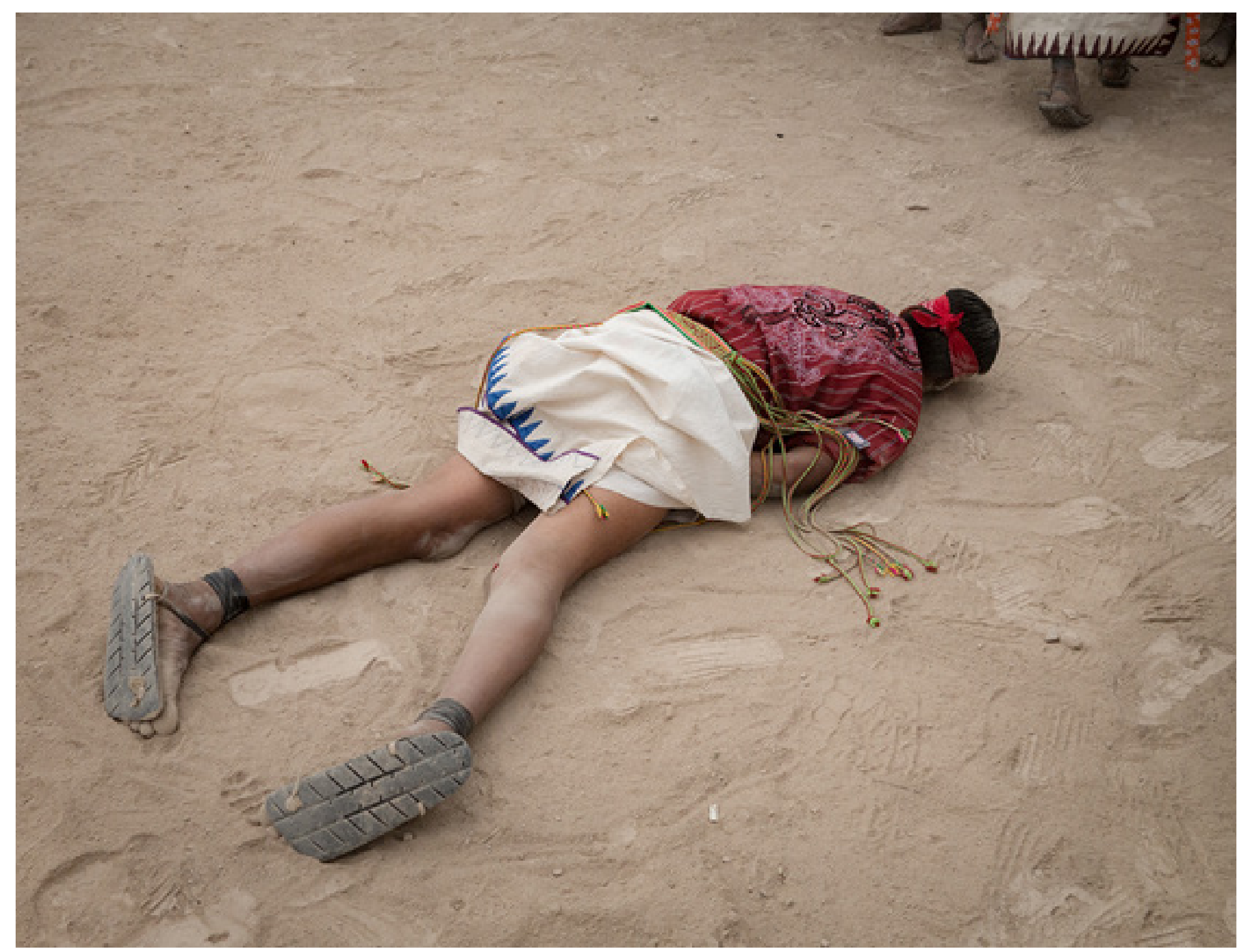

Si bien no hay ninguna intención de lastimar al adversario, a veces sucede -como en

el caso documentado en esta foto- que el contendiente resulte lastimado. Afortunadamente, el muchacho aquí retratado estaba de pie "como si nada" (como si nada hubiera Tehuerichi, abril de 2015 ocurrido) a los cinco minutos. 


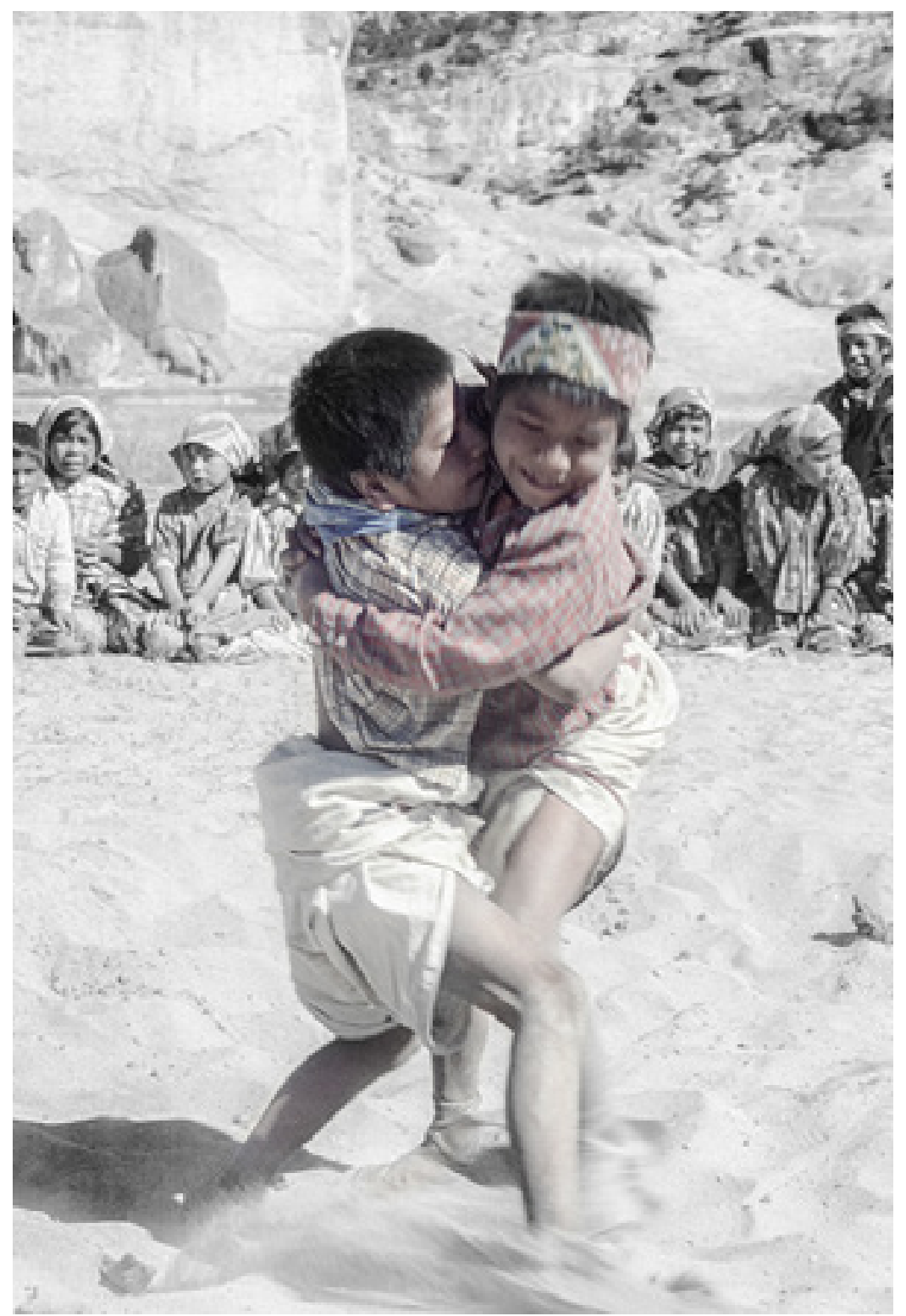

En este caso, se trata de un contexto no-ritual. Esta foto y las que siguen fueron tomadas en la Escuela Albergue de la comunidad. Por iniciativa del director de la escuela y por la correspondencia calendárica con el ciclo de Semana Santa, los niños y niñas de la escuela también experimentaron la emoción de las luchas. 


\section{Tehuerichi, abril de 2002}

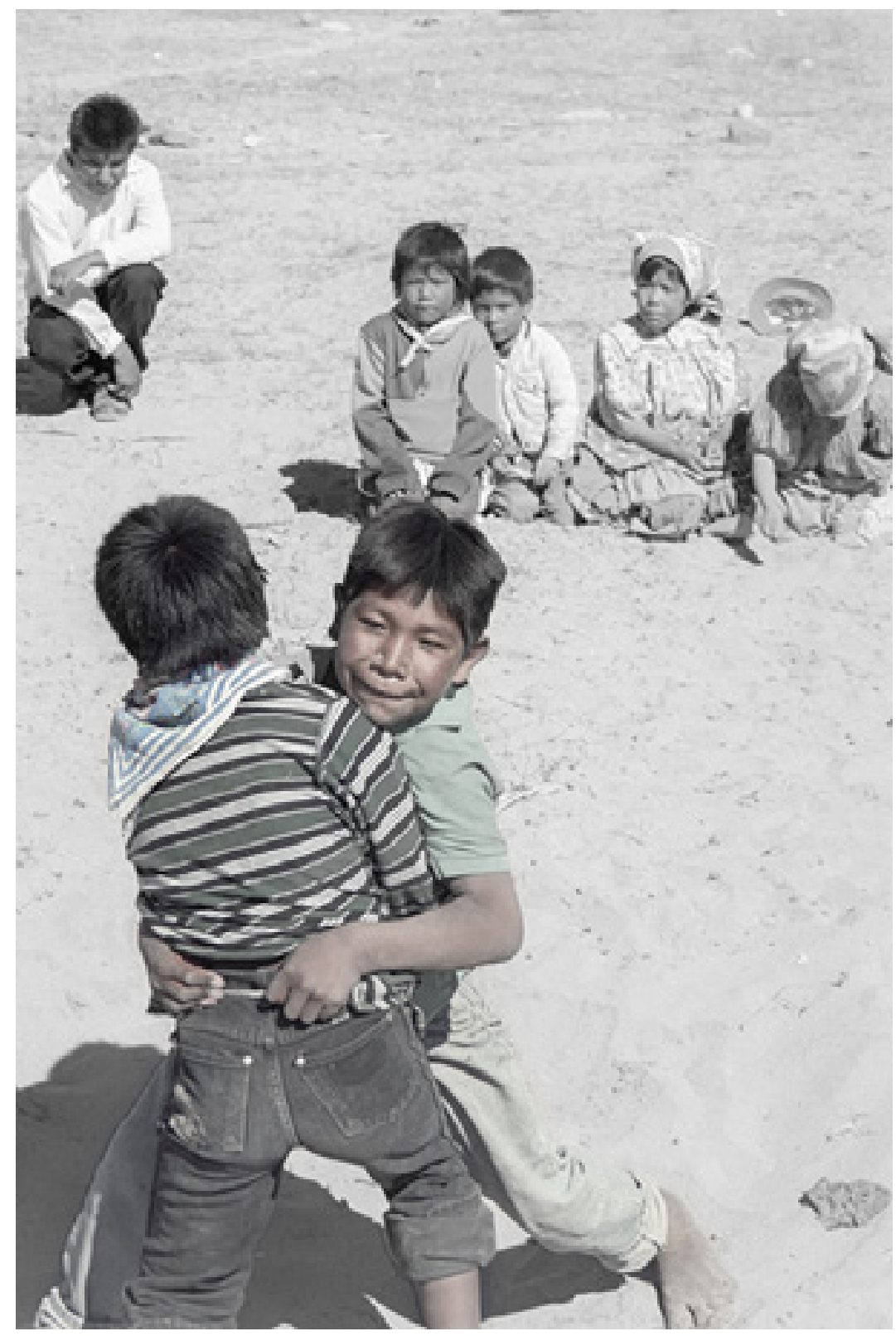

Bonfiglioli, C. (2021). Luchas rituales rarámuri. Iberoforum. Revista de Ciencias Sociales, Nueva Época, 1(2), 1-26, Ensayos fotográficos, e000192. https://doi.org/10.48102/if.2021.v1.n2.192 


\section{Tehuerichi, abril de 2002}
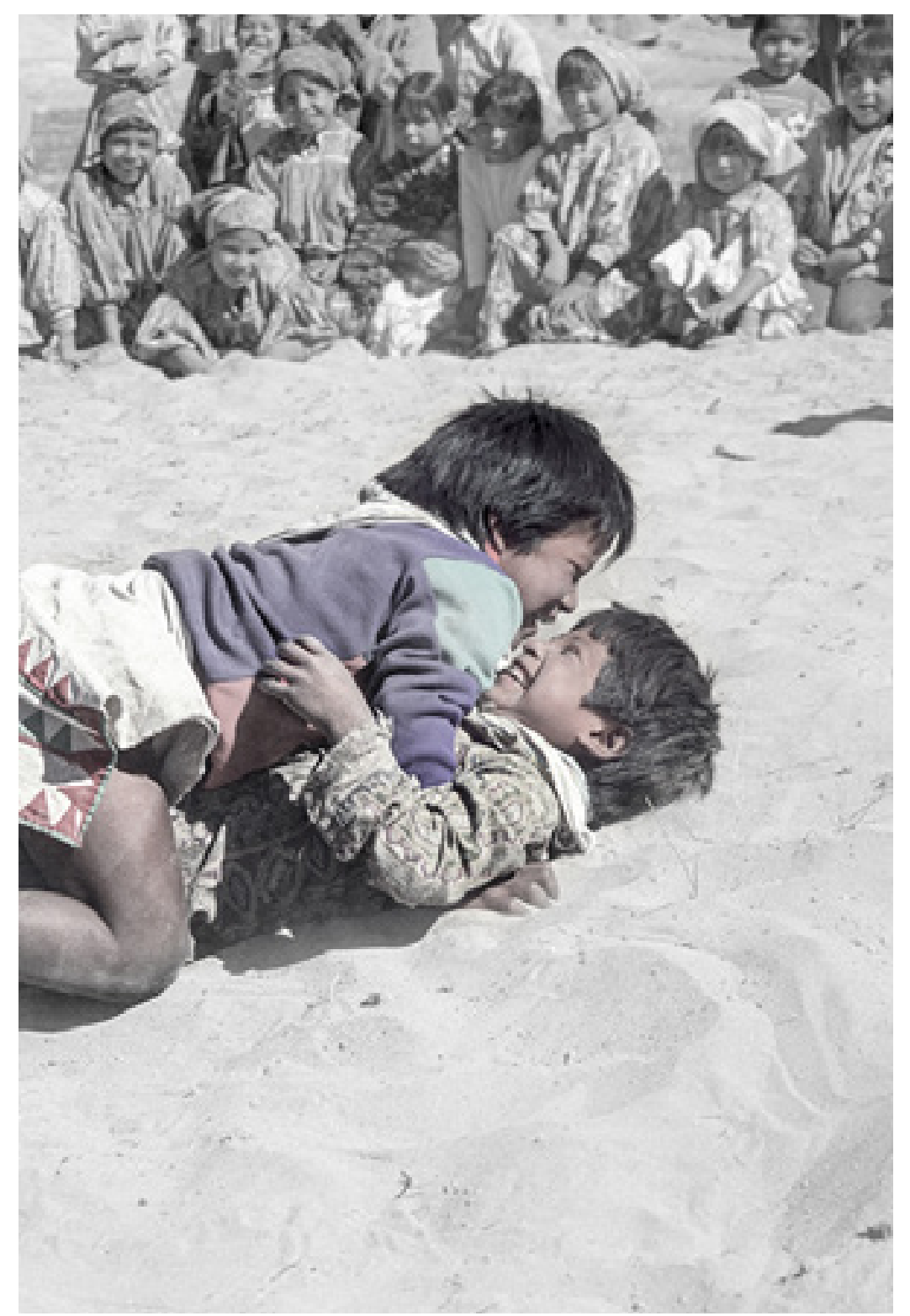


\section{Tehuerichi, abril de 2002}

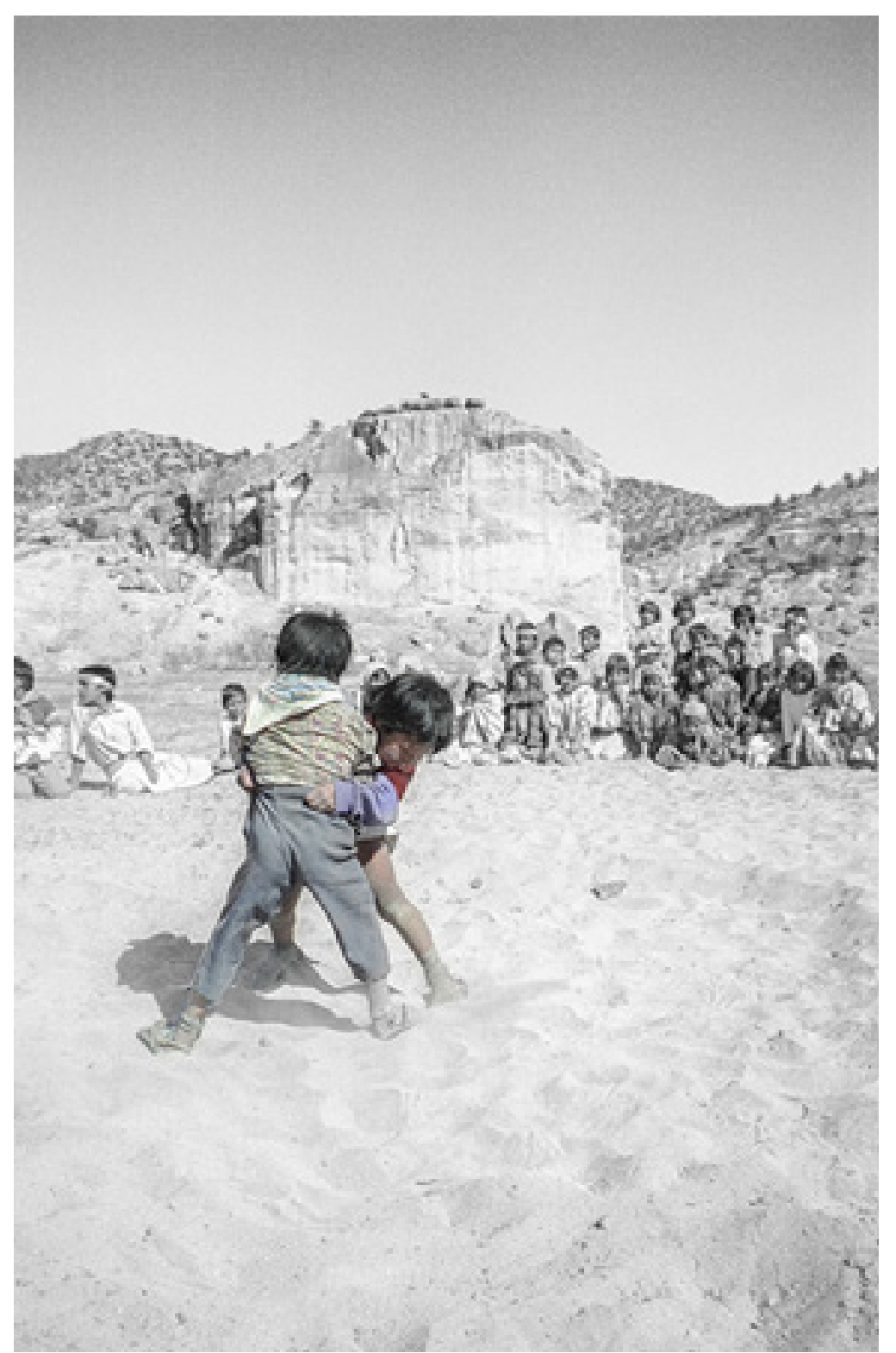




\section{Tehuerichi, abril de 2002}

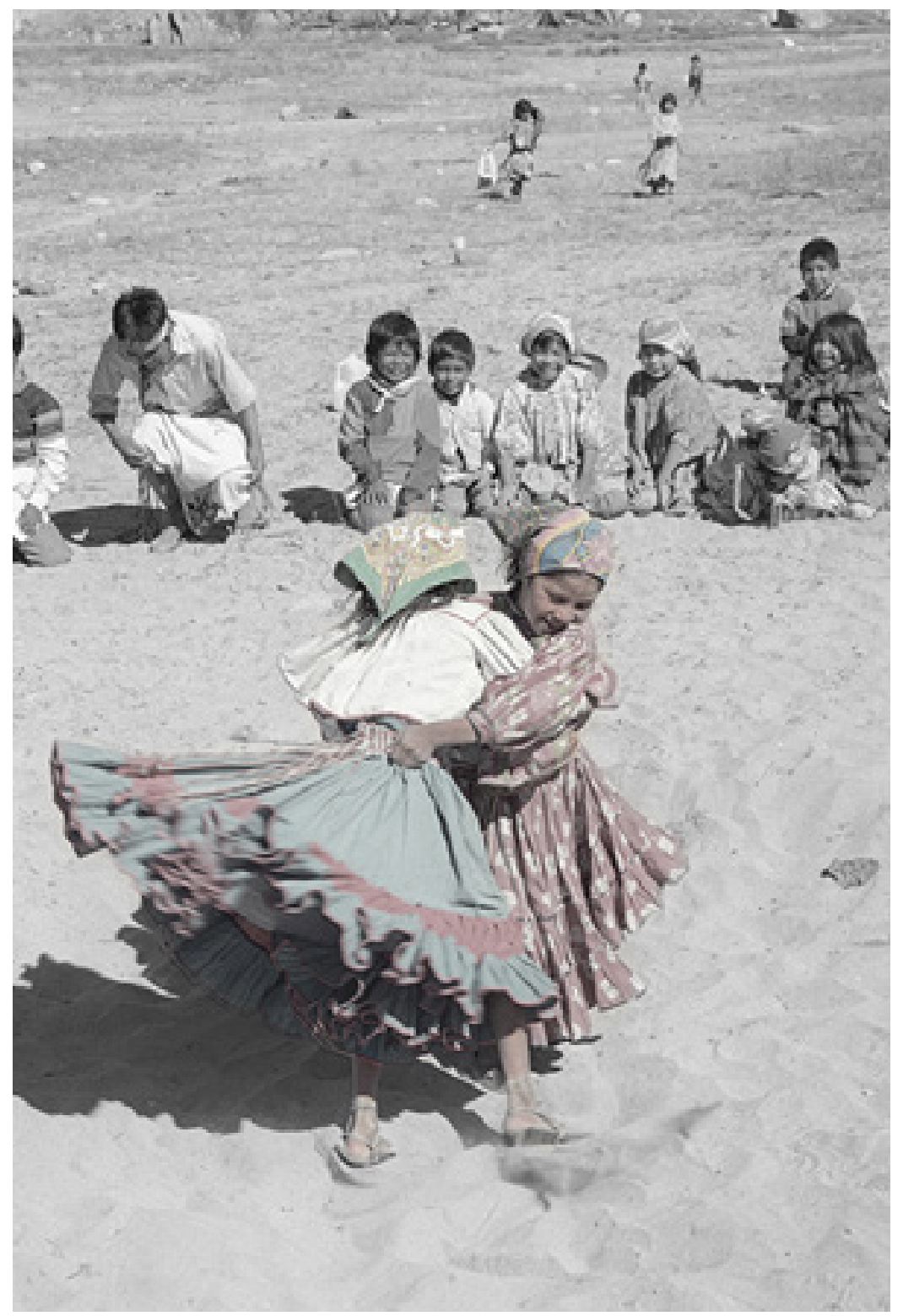

En el contexto ritual, nunca he visto luchas entre mujeres por el simple hecho de que los bandos antagónicos que se enfrentan en el escenario están constituidos por hombres. 